SYSTEMATIC REVIEW

\title{
EFFECTS OF FREQUENT KNEE BENDING AND OCCUPATION RELATED RISK FACTORS WITH KNEE JOINT PATHOLOGIES - A SYSTEMATIC REVIEW
}

\begin{abstract}
BACKGROUND AND AIMS

Knee pathologies are one of the most common musculoskeletal ailments with high rate of prevalence of degenerative knee changes causing functional limitations and participation restriction. Number of occupational exposures has shown positive correlation to Knee OA, associated with varying occupations and their demands.
\end{abstract}

\section{DATABASES AND ELIGIBILITY CRITERIA}

The observational studies were searched on the databases MEDLINE, PubMed, Google Scholar, PEDro and Cochrane Library from April to May 2019. It was ensured that all articles were full-text in English language whereas screening was executed on relevant titles and abstracts, evaluated on the basis of occupational hazards/risk factors and its impact on knee joint.

\section{RESULTS}

Number of studies represented varying occupational clusters that lead to certain risks factors according to demand. A positive relationship was indicated between age and Knee OA, along with squatting and knee pain that may results in elevated risk of disability and knee joint pathologies.

\section{CONCLUSION}

It was concluded that occupational exposures involved certain risk factors that may altered the knee joint function and increases the risk of Knee OA for future.

\section{KEYWORDS}

Knee Joint, Knee Injuries, Occupations, Risks, Health, Osteoarthritis.

\author{
Munira Mukadam \\ Lecturer \\ Ziauddin College of Rehabilitation \\ Sciences \\ Ziauddin University \\ Muniraali_@hotmail.com

\section{Mahnoor Khursheed} \\ House Officer \\ Dr. Ziauddin Hospital \\ mahnoorkhursheed@yahoo.com
}

[Mukadam M, Khursheed M. Association of frequent knee bending and occupation related risk factors with knee joint pathologies. Pak. J rehabil. 2019;8(2);4-11] 


\section{INTRODUCTION}

Knee pathologies are one of the most common musculoskeletal ailments in male and female affecting middle or late adulthood with high rate of prevalence of degenerative knee changes' ${ }^{1}$. In this context, Knee Osteoarthritis (OA) is reported to be world's 11 th most disability which causes functional limitations and participation restriction in affected individuals ${ }^{2}$. Moreover, knee pain and OA are also found to be common with chronicity that may leads to loss of work/job, joint surgery or disability ${ }^{3}$. Number of studies has been conducted to identify factors causing degenerative changes in the knee, some of which include obesity, poor lifestyle, injuries and nutritional deficiency ${ }^{4}$. Other risk factors such as age, being overweight (BMl>26), job-related activities; elevated levels of physical activity and mal-alignment of knee joint are the most predominant risk factors ${ }^{5}$. In addition, studies also suggested genetic component and sex as a possible risk factor, reporting higher prevalence of knee osteoarthritis in women over the age of 45 years ${ }^{3-5}$. However, among these risk factors knee bending has been proven to show a strong association with knee pathologies that may cause cartilage damage and meniscal lesions ${ }^{4}$. A review suggested that multiple risk factors are associated with varying occupations such as traumatic joint injuries, either direct or repetitive trauma activities, and decreased muscles strength etc 6 . In particular, it may lead to transfer the stress and shear forces to bony structures during repetitive squatting, bending or other movements causing knee pain and joint structure deterioration ${ }^{7}$. Despite, mechanisms linking occupation to $\mathrm{OA}$ are believed to be biomechanical factors ${ }^{7-8}$.

Previous studies showed that many occupations required tasks that involve abnormal load bearing on the lower extremity may leads to development of hip and knee osteoarthritis9-10. Many occupationrelated activities cause physiological to anatomical changes in knee joint that are usually due to changing of biomechanical characteristics of the human body ${ }^{9-11}$. According to a study, occupations which require squatting, carrying, heavy weight lifting, multiple sit ups with dairy farmers, factory workers and labors lead to adaptive changes in knee joint that gradually increases the risk of degenerative changes in knee ${ }^{12-13}$. Moreover, it has also been observed that long distance runners are prone to development of knee pain and articular changes in knee while athletes who played soccer are at high risk of developing occupation-related knee pathologies in comparison to non-players ${ }^{14}$. Furthermore, lifting of heavy loads is reported to be one of the most common occupational risk factor leads to the development of pathologies in several anatomical locations of the body involving knee ${ }^{15}$. Although, occupational factors are extensively studied in the formation and progression of knee osteoarthritis, synovitis and other degenerative processes which undergo the influence of high physical stress activities ${ }^{16}$. Number of studies demonstrated that under high stress conditions, frequent and repetitive knee bending during different occupational activities such as squatting and heavy lifting that occurs with manual workers causes repetitive trauma to knee structures that leads to frequent pain in knee joint ${ }^{17-20}$. Moreover, prevalence of knee pain was highest among all the musculoskeletal pain as reported in the study ${ }^{21}$. Several studies reported that activities which require flexion of the knee joint beyond 90 degrees are believed to exert a greater amount of load across the whole knee joint which potentially damages the articular cartilage and other soft tissues of knee. Thus, excessive loading and frequent knee bending during any occupational or daily living activities increases the risk factors in pathogenesis of knee joint leading to occupation-related knee pathologies $^{22}$. As for Knee OA, certain risk factors have been identified but are not well-established due to lack of studies according to specific occupations and its hazards. Several studies has also indicated that work-related activities increased pressure on the joint surface thereby high mechanical stress due to squatting, kneeling, lifting and stairs climbing is a crucial risk factor in an occupation ${ }^{23}$. Moreover, considerable number of systematic reviews has evaluated increased risk of Knee OA due to varying occupational clusters and their demands. Despite of the fact, limited number of studies has analyzed dose-response relationship between occupational hazards and Knee OA that should be considered as an important argument in order to infer causality.

Several studies have proposed limited number of treatment options that predominantly included NSAIDs (Non-steroidal Anti-Inflammatory Drugs) for the management of knee pain and weight in order to reduce mechanical stress across joint ${ }^{24-25}$. Moreover, as the disease progress, surgery inclusive of total knee replacement is an optimum option for patient recovery, however the pathology is irreversible and have gradual progression therefore underscores importance of preventative measures ${ }^{26}$. Consecutively, multiple options are available to consider potentially modifiable occupational risk factor as this systematic review only included observational studies that demonstrated occupational clusters, related risk factors and study outcomes. Further reviews are therefore should be conducted as limited quantitative analysis would be helpful to identify occupational activities in context of known risk factors and its impact on knee joint.

\section{METHODOLOGY}

The systematic review has followed Preferred Reporting Items for Systematic Reviews and 
Meta-Analyses (PRISMA) guidelines.

\section{Searching Strategy and Databases}

The authors identified and searched studies on learning resource centers and electronic databases that included MEDLINE, PubMed, Google Scholar, PEDro and Cochrane Library. The databases were searched from April to May 2019 by using keywords such as "Knee Joint Pathologies", "Knee Pain", "Knee Osteoarthritis", and "Occupational Hazards/Risk Factors." Titles or abstracts were thoroughly reviewed and were excluded if not relevant to specified terms.

\section{Eligible Studies and Characteristics}

The observational studies included "Cross-sectional", "Cohort", "Longitudinal" and "Exploratory" designs that were selected from the tenure of 2012 to 2019 respectively. It was ensured that all articles were full-text in English language; however studies with a language barrier were excluded.

\section{Study Selection and Data Extraction}

Screening was executed on relevant titles and/or abstracts were included in the systematic review. All studies were evaluated on the basis of occupational hazards/risk factors and its impact on knee joint. Furthermore, risk and exposure (Odds Ratio/Relative Risk) was also identified in relevance to knee loading and kinematics comprised of occupational activities (squatting, weight lifting, kneeling, long sitting with bent knees, stairs climbing, running and long standing). Whereas, outcomes on prevalence, MRI, radiographs were also considered. Moreover, the sources of all the articles were assessed. Whereas list of references of all identified pertinent studies were also searched.

\section{Quality Appraisal}

The quality of the involved studies was assessed and risk of bias was measured on six domains comprised of funding and conflict of interest, outcome assessment, exposure assessment, confounding factors, attrition and analysis (adapted from Verbeek et al'2017).

\section{RESULTS}

\section{Selection of Studies}

A total number of 40 records analyzed from learning resource centers and databases. The articles relevant to context of objective were identified for screening on the basis of eligibility. Only 12 full-text observational studies conducted during 2012 to 2019 were included as shown in Figure-1.

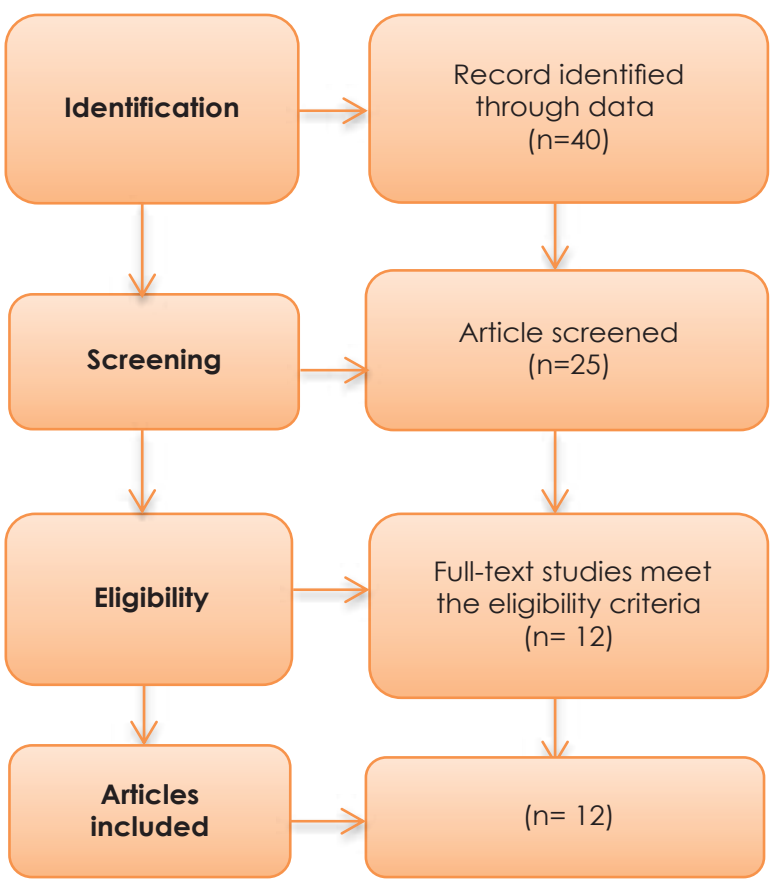

Figure.1 Flow diagram on identification and screening of eligible studies for inclusion

\section{Study Characteristics}

Total 12 observational studies were included in the study that included number of cohort and cross-sectional designs, however only one study is longitudinal and exploratory respectively. Occupational exposures in different occupations were identified and its impact on knee joint was screened to determine the outcomes related to knee joint pathologies.

\section{Synthesis of Studies}

All the studies represented large sample size except Kajakas et all 12018 who conducted an exploratory study on a relatively small sample. A number of studies ${ }^{1,4,7,8,10,11,12,19,20,27,28,29}$ represented varying occupational clusters inclusive of office workers, professional players, manual occupations and labors (highest to lowest) that lead to certain risks factors according to demand while occupation was unidentified in some studies $4,11,12,19,20$. It was observed that occupational exposures consisted of obesity, prolonged working hours, extensive workload and existing knee pathologies that may increase the risk of knee joint pathologies, in particular, Knee Osteoarthritis. Similarly, Fernandes et $\mathrm{al}^{8}$ and Barbour et $\mathrm{al}^{12}$ represented high level of physical activity as a crucial risk factor that may leads to elevated risk of OA. Whereas, Ezzat et al ${ }^{20}$ determined a dose-response curve on Cumulative Occupational physical load (COPL) for Knee OA that was effective to evaluate the outcome. Besides, Van et $\mathrm{al}^{4}$, Kajakas et $\mathrm{al}^{11}$ and Virayavanich et $\mathrm{al}^{19}$ indicated that frequent knee bending, prolonged kneeling and loading may also induced the risk of meniscal lesions, cartilage damage and 
synovitis that may alters gait parameters. While study of Solovieva et $\mathrm{al}^{28}$, Rachmi et $\mathrm{a}^{29}$ and Hawamdeh et $\mathrm{al}^{27}$ indicated a positive relationship between age and Knee $\mathrm{OA}$, along with squatting and knee pain that may results in elevated age-adjusted risk of disability and OA. Although, exposures (Odds Ratio/Relative Risk) were identified but not included in the study analysis while unidentified occupation in studies also serve as limitation. The characteristics of studies are depicted in Table-1.

\begin{tabular}{|c|c|c|c|c|c|}
\hline $\begin{array}{l}\text { Author } \\
\text { (Year) }\end{array}$ & \begin{tabular}{|l|} 
Sample \\
Size (n)
\end{tabular} & Study Design & Occupation & Risk Factors & Outcomes \\
\hline $\begin{array}{l}\text { Daneshmandi et al }{ }^{1} \\
\text { (2017) }\end{array}$ & 447 & $\begin{array}{l}\text { Cross- } \\
\text { sectional }\end{array}$ & Office Workers & $\begin{array}{l}\text { Prolonged sitting } \\
\text { behavior }\end{array}$ & Knee pain \\
\hline $\begin{array}{l}\text { Leung et al } \\
(2018)\end{array}$ & 63,257 & Cohort & Unidentified & $\begin{array}{l}\text { Extended duration } \\
\text { of physical activity }\end{array}$ & Knee OA \\
\hline $\begin{array}{l}\text { Fernandes et al }{ }^{8} \\
(2018)\end{array}$ & 470 & $\begin{array}{l}\text { Cross- } \\
\text { sectional }\end{array}$ & $\begin{array}{l}\text { Retired } \\
\text { Professional } \\
\text { Footballers }\end{array}$ & Knee Injury & $\begin{array}{l}\text { Knee OA were two } \\
\text { to three times higher } \\
\text { in footballers }\end{array}$ \\
\hline $\begin{array}{l}\text { Van et al }{ }^{4} \\
(2018)\end{array}$ & 594 & Cohort & Unidentified & Knee OA & $\begin{array}{l}\text { Hoffa/Effusion Synovitis } \\
\text { due to prolonged } \\
\text { kneeling }\end{array}$ \\
\hline $\begin{array}{l}\text { Solovieva et al }{ }^{28} \\
(2018)\end{array}$ & $\begin{array}{l}1,135 \\
654\end{array}$ & Cohort & $\begin{array}{l}\text { Manual } \\
\text { Occupations }\end{array}$ & $\begin{array}{l}\text { Education and } \\
\text { physical workload } \\
\text { factors }\end{array}$ & $\begin{array}{l}\text { Elevated age-adjusted } \\
\text { risk of disability } \\
\text { retirement as a result } \\
\text { of hip OA }\end{array}$ \\
\hline $\begin{array}{l}\text { Rachmi et al }{ }^{29} \\
(2018)\end{array}$ & 117 & $\begin{array}{l}\text { Cross- } \\
\text { sectional }\end{array}$ & Dairy Farmers & $\begin{array}{l}\text { Prolonged } \\
\text { working } \\
\text { hours }\end{array}$ & $\begin{array}{l}\text { A positive relation } \\
\text { between knee pain } \\
\text { and the squatting } \\
\text { work position }\end{array}$ \\
\hline $\begin{array}{l}\text { Seok et al }{ }^{10} \\
(2017)\end{array}$ & 9,905 & $\begin{array}{l}\text { Cross- } \\
\text { sectional }\end{array}$ & $\begin{array}{l}\text { Manual labor } \\
\text { (highest to lowest) }\end{array}$ & $\begin{array}{l}\text { Physical labor } \\
\text { can induce and } \\
\text { develop OA }\end{array}$ & $\begin{array}{l}\text { Knee OA dependent } \\
\text { upon the occupational } \\
\text { clusters }\end{array}$ \\
\hline $\begin{array}{l}\text { Kajakas et al }{ }^{11} \\
(2014)\end{array}$ & 10 & Exploratory & Unidentified & Knee OA & $\begin{array}{l}\text { Sustained static deep- } \\
\text { knee flexion kneeling } \\
\text { alter knee joint gait } \\
\text { parameters }\end{array}$ \\
\hline $\begin{array}{l}\text { Barbour et al }{ }^{12} \\
(2013)\end{array}$ & 1,522 & Cohort & Unidentified & $\begin{array}{l}\text { Incident knee } \\
\text { radiographic OA } \\
\text { (ROA) and } \\
\text { Incident knee } \\
\text { symptomatic } \\
\text { ROA (sROA) }\end{array}$ & $\begin{array}{l}\text { Elevated risk of knee } \\
\text { OA in individuals with } \\
\text { highest level of } \\
\text { physical activity }\end{array}$ \\
\hline $\begin{array}{l}\text { Virayavanich et } \mathrm{al}^{19} \\
(2013)\end{array}$ & 115 & Longitudinal & Unidentified & $\begin{array}{l}\text { Increased risk of } \\
\text { progression of } \\
\text { cartilage and } \\
\text { meniscal lesion }\end{array}$ & $\begin{array}{l}\text { Frequent knee } \\
\text { bending were } \\
\text { more likely to show } \\
\text { progression of } \\
\text { cartilage damage } \\
\text { and meniscal } \\
\text { abnormalities }\end{array}$ \\
\hline $\begin{array}{l}\text { Ezzat et al } \\
(2012)\end{array}$ & 327 & $\begin{array}{l}\text { Cross- } \\
\text { sectional }\end{array}$ & Unidentified & $\begin{array}{l}\text { Cumulative } \\
\text { Occupational } \\
\text { physical load } \\
\text { for Knee OA }\end{array}$ & $\begin{array}{l}\text { A dose response } \\
\text { relationship between } \\
\text { Cumulative } \\
\text { Occupational } \\
\text { Physical Load (COPL) } \\
\text { and Symptomatic } \\
\text { Radiographic } \\
\text { Osteoarthritis (SOA) }\end{array}$ \\
\hline $\begin{array}{l}\text { Hawamdeh et al } \\
(2013)\end{array}$ & 214 & $\begin{array}{l}\text { Cross- } \\
\text { sectional }\end{array}$ & $\begin{array}{l}\text { Private and } \\
\text { Government } \\
\text { Employees }\end{array}$ & Knee OA & $\begin{array}{l}\text { Moderate positive } \\
\text { correlation between } \\
\text { ageand radiographic } \\
\text { severity of KOA }\end{array}$ \\
\hline
\end{tabular}




\section{Risk of Bias in Studies}

All the studies $1,4,7,8,10,11,12,20,27,28$ showed low risk of bias in domain of funding and conflict of interest except Rachmi et a ${ }^{29} 2018$ that showed high risk. Leung et $\mathrm{al}^{7} 2018$ showed high risk of bias, Solovieva et $\mathrm{al}^{28}$ 2018 and Ezzat et $\mathrm{al}^{20} 2012$ showed Unclear risk in outcome assessment. Moreover, Rachmi et $\mathrm{al}^{29}$ 2018, Kajakas et al ${ }^{11} 2014$, Barbour et al ${ }^{12} 2013$ and Hawamdeh et al ${ }^{27} 2013$ showed high risk of bias in exposure assessment. Studies of Leung et $\mathrm{al}^{7} 2018$, Rachmi et $a^{29} 2018$, Kajakas et $a^{11} 2014$ Ezzat et $a^{20}$ 2012 and Hawamdeh et $a^{27} 2013$ also showed high risk of bias in the domain of confounding factors. Attrition was found to lacking in nearly all the studies $1,4,8,11,20,27,28$ except Leung et $\mathrm{al}^{7}$ 2018, Seok et al $^{10} 2017$ and Barbour et al $^{12} 2013$ that showed unclear risk. However, analysis was found in all studies $1,4,7,8,10,11,12,19,20,27,28,29$, hence showed low risk of bias as demonstrated in Table-2.

\section{DISCUSSION}

This systematic review demonstrated significant occupational hazards, affecting knee kinematics that may progress to knee pain, OA or other pathologies. The analysis of total 12 studies revealed positive relationship between different occupation and knee problems. A study compared the outcomes for knee pain between physically active programmers and inactive students found high rate of knee pain among the programmers due to long term knee bending'. Similarly, findings of another study revealed that during squatting there is a significant effect on knee angle especially at 60 and 90 degrees of squatting produces greater amount of compressive forces that act at the Patellofemoral joint ${ }^{11,19}$. In addition, these forces produces friction and excessive stress on the soft tissues that leads to early osteoarthritis and bursitis of the knee, although this squatting posture is used in number of occupations that may occur as risks for knee pathologies ${ }^{11,19}$. Furthermore, a study assessed the effects of occupational kneeling on specific compartment of knee joint, considering Patellofemoral joint and the Tibiofemoral joint showed that there is an association between occupational kneeling and degenerative changes in the knee joint especially in the trade seniority ${ }^{28-29}$. Similar to this, findings of another review stated that participation in certain sports can cause knee joint osteoarthritis especially in the participants who were involved in soccer; elite-level long-distance running, weight lifting and wrestling should be targeted for risk-reduction strategies as they had an increased rate of prevalence of knee pain and osteoarthritis ${ }^{8}$. Moreover, another study suggested an effective use of a Whole Organ MRI to detect knee cartilage lesions; this was confirmed by an experiment that analyzes the effect of repetitive knee bending due to stair climbing, knee, squatting and weight lifting on daily basis ${ }^{12,20}$. It was concluded that there is a high prevalence of knee cartilage damage due to frequent and repetitive knee bending with an increased risk of progression to further damage or meniscal lesions ${ }^{8}$.
Knee bending activities are statistically known to cause degenerative diseases in the knee joint including synovitis ${ }^{4}$. The terms used to describe various sounds around the knee joint including popping, catching, clicking, snapping, crunching or grinding etc. Previous studies have investigated the mechanism related with changes in the knee leading to crepitus ${ }^{1-5}$. However, it has been observed that long term knee bending especially during long sitting in the office workers have been reported to cause the sound ${ }^{4}$. This knee crepitus in such occupations is an initial indication of future knee pathologies either in the bony structures or in the synovium or soft tissues of the knee joint ${ }^{4,27}$. Similarly, for manual laborers kneeling and squatting accompanied with heavy weight lifting has been reported to have routine postures for their daily life showed an increased prevalence and elevated risk of knee meniscal injuries, degenerative knee pathologies and knee cartilage wear and tear that were significantly associated with these routine postures of laborers ${ }^{10}$. This derives strong evidence regarding occupational postures that specifically involved knee bending has frequent and long term association with development and progression of knee problems ${ }^{10}$. Multiple studies have reported occupational activities as risk factors for Knee OA and pain 1,7,4,27. However, yet several studies were based on qualitative analysis only few are quantitative, therefore more studies required to be conducted on variety of risk factors and hazards for optimal values in the literature ${ }^{30-31}$. A meta-analysis, conducted on 51 studies with more than 5 hundred thousand sample size concluded that variety of occupational factors are associated through biomechanical pathways thereby increases the risk of Knee OA up to $60 \%^{30-32}$. Similarly, a smaller groups of studies in a review demonstrated a risk of persistent knee pain that may derived from different occupational exposures ${ }^{11,30}$. It was observed that hospital-based studies yield increased risks of Knee $\mathrm{OA}$ in comparison to community-based studies ${ }^{30-33}$ This increased risk provides estimation may be due to occurrence of one more diseases. Therefore, where occupational risks factors were not screened as a primary outcome, the risks for Knee OA might have occurred due to secondary complications ${ }^{34-35}$. In conclusion this systematic review is entirely based on limited number of observational studies, based with varying occupational clusters and outcomes. Moreover, full-text articles in English language was included only, thus number of studies had been excluded due to language preference. Furthermore, studies also unable to report ethnic difference in occupational risk factors that may serve as an important factor in analyzing the exposure. In addition, biomechanical pathways can also be considered for an effective approach in risk factor analysis and outcome. Therefore, quantitative analysis consisted of multicenter trials or experimental studies are required considering exposure analysis and interpretation to identify occupational hazards and its impact on knee joint and related pathologies. 
Table.2 Risk of bias of studies for six domains $(n=12)$

\begin{tabular}{|c|c|c|c|c|c|c|}
\hline Studies & 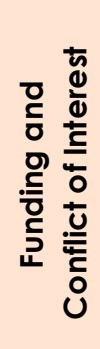 & 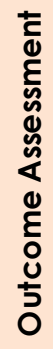 & 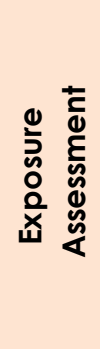 & 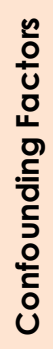 & 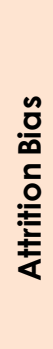 & $\frac{\frac{n}{n}}{\frac{2}{c}}$ \\
\hline $\begin{array}{l}\text { Daneshmandiet al } \\
\text { (2017) }\end{array}$ & + & + & + & + & - & + \\
\hline Leung etal ${ }^{7}$ (2018) & + & - & + & - & $?$ & + \\
\hline Fernandes et al $^{8}$ (2018) & + & + & + & + & - & + \\
\hline Van et $a^{4}(2018)$ & + & + & + & + & - & + \\
\hline Solovieva etal ${ }^{28}$ (2018) & + & $?$ & + & + & - & + \\
\hline Rachmi et al $^{29}$ (2018) & - & + & - & - & - & + \\
\hline Seok et al ${ }^{10}$ (2017) & + & + & + & + & $?$ & + \\
\hline Kajakas et al $^{11}$ (2014) & + & + & - & - & - & + \\
\hline Barbour etal $^{12}$ (2013) & + & + & - & + & $?$ & + \\
\hline $\begin{array}{l}\text { Virayavanich et al } \\
\text { (2013) }\end{array}$ & + & + & + & + & - & + \\
\hline Ezzat et al ${ }^{20}$ (2012) & + & $?$ & + & - & - & + \\
\hline $\begin{array}{l}\text { Hawamdeh et al } \\
(2013)\end{array}$ & + & + & - & - & - & + \\
\hline
\end{tabular}

\section{CONCLUSION}

It was concluded that occupational exposures involved number of risks factors that may altered the knee joint function and increases the risk of Knee OA for future. The occupational clusters i.e. manual labor from highest to lowest involving frequent and repetitive knee bending also increases risk of developing knee pathologies which includes degenerative changes in the knee such as meniscal lesions, synovitis and cartilaginous damage due to stress and friction thereby reduces knee function. Further risk factors should also be considered along with more studies involving multicenter trials to approach an outcome effectively.

\section{Strengths and Limitations}

This systematic review is exclusive to analyze the occupational risk factors and its impact on knee considering multiple occupational clusters. However, it consisted of only few observational studies, also the methodological quality of some studies was inadequate.

\section{Future Recommendations}

Large scale, multi-center trials should be considered to analyze the magnitude of occupational hazards and knee-related pathologies. Further variables must also be taken in to account in order to evaluate the study objectives more precisely.

\section{Conflict of Interest}

The authors declared no conflicting interests regarding publication or authorship of this systematic review.

\section{Funding}

No financial support was received by authors for this systematic review. 


\section{REFERENCES}

[1] Daneshmandi $H$, Choobineh A, Ghaem H, Karimi M. Adverse effects of prolonged sitting behavior on the general health of office workers. J. Lifestyle Med. $2017 ; 7(2): 69$.

[2] Gholami J, Mansournia MA, Davatchi F, Mohammad K, Hosseini H, Majdzadeh R. Are daily physical activities risk factors for knee osteoarthritis?. Int J Rheu Dis. 2016;19(3):241-7.

[3] O'Neill TW, McCabe PS, McBeth J. Update on the epidemiology, risk factors and disease outcomes of osteoarthritis. Best Pract Res Cl Rh. $2018 ; 32(2): 312-26$.

[4] Van Ginckel A, Wittoek R, De Mits S, Calders P. Repetitive knee bending and synovitis in people at risk and with knee osteoarthritis: Data from the FNIH Osteoarthritis Biomarkers Consortium. Arthritis Care Res. 2018.

[5] Ezzat AM, Li LC. Occupational physical loading tasks and knee osteoarthritis: a review of the evidence. Physiother Can. 2014 ;66(1):91-107.

[6] Bidassie B, Barany JW, McCabe GP, Duffy VG, Witz SM. Occupational and lifestyle risk factors in a wellness programme associated with low back injuries in a Midwest university. Theor Issues Ergon Sci. 2016 ;17(3):239-66.

Leung YY, Razak HR, Talaei M, Ang LW, Yuan

[7] JM, Koh WP. Duration of physical activity, sitting, sleep and the risk of total knee replacement among Chinese in Singapore, the Singapore Chinese Health Study. PloS one. $2018 ; 13(9)$ :e0202554.

[8] Fernandes GS, Parekh SM, Moses J, Fuller C, Scammell B, Batt ME, Zhang W, Doherty $M$. Prevalence of knee pain, radiographic osteoarthritis and arthroplasty in retired professional footballers compared with men in the general population: a cross-sectional study. Br J Sports Med. $2018 ; 52(10): 678-83$.

[9] Gignac MA, Irvin E, Cullen K, Van Eerd D, Beaton DE, Mahood Q, McLeod C, Backman CL. Men and women's occupational activities and the risk of developing osteoarthritis of the knee, hip or hands: A systematic review and recommendations for future research. Arthritis Care Res. 2019

[10] Seok H, Choi SJ, Yoon JH, Song GG, Won JU, Kim JH, Roh J, Jung JH. The association between osteoarthritis and occupational clusters in the Korean population: A nationwide study. PLoS One. 2017;12(1).

[11] Kajaks T, Costigan P. The effect of sustained static kneeling on kinetic and kinematic knee joint gait parameters. Appl. Ergon. 2015

[12] ;46:224-30.

Barbour KE, Hootman JM, Helmick CG, Murphy $L B$, Theis KA, Schwartz TA, Kalsbeek WD, Renner JB, Jordan JM. Meeting physical activity guidelines and the risk of incident knee osteoarthritis: a population-based prospective cohort study. Arthritis Care Res. 2014

[13] ;66(1):139-46.

Yousuf AW, Yousuf AM, Erum AU. Occupation and sports participation as risk factors for the development and progression of knee
[14] Osteoarthritis. Int J Res Med Sci. $2017 ; 5(6): 2278$ Yucesoy B, Charles LE, Baker B, Burchfiel CM. Occupational and genetic risk factors for osteoarthritis: a review. Work. 2015 ;50(2):261-73.

[15] Ribeiro T, Serranheira F, Loureiro H. Work related musculoskeletal disorders in primary health care nurses. Appl Nurs Res. 2017 ;33:72-7.

[16] Richmond SA, Fukuchi RK, Ezzat A, Schneider K, Schneider G, Emery CA. Are joint injuries, sport activity, physical activity, obesity, or occupational activities predictors for osteoarthritis? A systematic review. J Orthop Sport Phys. $2013 ; 43(8): 515-B 19$.

[17] Antwi-Afari MF, Li H, Edwards DJ, Pärn EA, Seo $\mathrm{J}$, Wong AY. Biomechanical analysis of risk factors for work-related musculoskeletal disorders during repetitive lifting task in construction workers. Automat Constr. 2017 ;83:41-7.

[18] Tennant LM, Chong HC, Acker SM. The effects of a simulated occupational kneeling exposure on squat mechanics and knee joint load during gait. Ergonomics. 2018 ;61(6):839-52.

[19] Virayavanich W, Alizai H, Baum T, Nardo L, Nevitt MC, Lynch JA, McCulloch CE, Link TM. Association of frequent knee bending activity with focal knee lesions detected with 3T magnetic resonance imaging: data from the osteoarthritis initiative. Arthritis Care Res. 2013 ;65(9):1441-8.

[20] Ezzat AM, Cibere J, Koehoorn M, Sayre EC, Li L. Cumulative occupational physical load as risk factor for knee osteoarthritis. Arthritis and Rheumatism. 2012 Oct 1;64:S473-74.

[21] Vina ER, Kwoh CK. Epidemiology of osteoarthritis: literature update. Curr Opin Rheumatol.. $2018 ; 30(2): 160$.

[22] Heidari B. Knee osteoarthritis prevalence, risk factors, pathogenesis and features: Part I. Caspian J Intern Med. $2011 ; 2(2): 205$.

[23] Mahmoudian A, Van Assche D, Herzog W, Luyten FP. Towards secondary prevention of early knee osteoarthritis. RMD open. 2018 ;4(2):e000468.

[24] Mora JC, Przkora R, Cruz-Almeida Y. Knee osteoarthritis: pathophysiology and current treatment modalities. J. Pain Res. 2018;1 1:2189.

[25] Grazina R, Andrade R, Bastos R, Costa D, Pereira R, Marinhas J, Maestro A, Espregueira-Mendes J. Clinical management in early $O A$. InOsteochondral Tissue Engineering 2018 (pp. 111-135). Springer, Cham.

[26] Cissell DD. Toward Detection of Early Degeneration, Restoration of Function, and Evaluation of Regeneration in Cartilage. University of California, Davis; 2016.

[27] Hawamdeh ZM, Al-Ajlouni JM. The clinical pattern of knee osteoarthritis in Jordan: a hospital based study. Int. J. Med. Sci. 2013;10(6):790.

[28] Solovieva S, Kontio T, Viikari-Juntura E. Occupation, Physical Workload Factors, and 
Disability Retirement as a Result of Hip Osteoarthritis in Finland, 2005-2013. J. Rheumatol. $2018 ; 45(4): 555-62$.

[29] Rachmi IM, Werdhani RA, Murdana IN. Association of knee pain with working position and other factors among dairy farmers: A study in West Java, Indonesia. J. Phys. Conf. Ser. 2018 (Vol. 1073, No. 4, P. 042011). IOP Publishing.

[30] Verbeek J, Mischke C, Robinson R, ljaz S, Kuijer $P$, Kievit A, Ojajärvi A, Neuvonen K. Occupational exposure to knee loading and the risk of osteoarthritis of the knee: a systematic review and a dose-response meta-analysis. Saf Health Work. 2017 ;8(2):130-42.

[31] Yucesoy B, Charles LE, Baker B, Burchfiel CM. Occupational and genetic risk factors for osteoarthritis: a review. Work. 2015 ;50(2):261-73.
[32] Gardiner BS, Woodhouse FG, Besier TF, Grodzinsky AJ, Lloyd DG, Zhang L, Smith DW. Predicting knee osteoarthritis. Ann Biomed Eng. $2016 ; 44(1): 222-33$.

[33] Heuch I, Heuch I, Hagen K, Zwart JA. Physical activity level at work and risk of chronic low back pain: A follow-up in the Nord-Trøndelag Health Study. PLoS One. 2017;12(4).

[34] Sámano-Ríos ML, ljaz S, Ruotsalainen J, Breslin FC, Gummesson K, Verbeek J. Occupational safety and health interventions to protect young workers from hazardous work-A scoping review. Saf. Sci. $2019 ; 113: 389-403$.

[35] Alentorn-Geli E, Samuelsson K, Musahl V, Green CL, Bhandari M, Karlsson J. The association of recreational and competitive running with hip and knee osteoarthritis: a systematic review and meta-analysis. J Orthop Sport Phys.2017;47(6):373-90. 